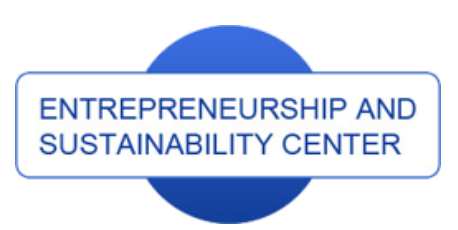

Publisher

http://jssidoi.org/esc/home enterprise

europe

network

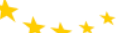

Business Support on Your Doorstep

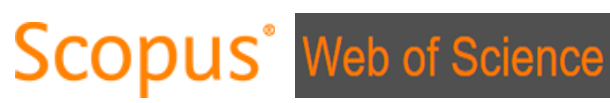

1) Clarivate

\title{
FINANCIAL, ORGANISATIONAL AND INFORMATIVE INVOLVEMENT OF THE SOCIETY IN SOCIAL INNOVATION PROCESSES IN LATVIA*
}

\author{
Karine Oganisjana1 $^{1}$, Svetlana Surikova ${ }^{2}$, Konstantins Kozlovskis ${ }^{3}$, Anna Svirina ${ }^{4}$ \\ ${ }^{1,3}$ Riga Technical University, 6 Kalnciema Street, Riga, Latvia, \\ ${ }^{2}$ University of Latvia, 1 Imantas 7 linija, Riga, Latvia \\ ${ }^{4}$ Kazan National Research Technical University, K. Marx St., Kazan, Russia
}

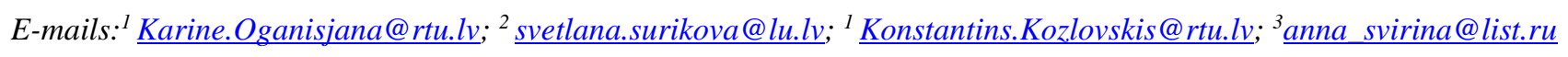

Received 30 March 2018; accepted 25 August 2018; published 30 September 2018

\begin{abstract}
Social innovation brings to inclusion and wellbeing, improving the quality of life and socio-economic performance and enhancing the society's collective power and resources. Therefore, it is of utmost importance to promote social innovation processes in any society, providing research for getting the understanding of different aspects of it, including the main actors and the extent to which they are involved in social innovation. The research presented in this paper reveals the main stakeholders of social innovation and analyses the methodology elaborated by the authors for determining the involvement of the society in social innovation processes at financial, organisational and informative levels. Corresponding indices defined and determined for the case of Latvia reveal that the level of overall involvement of the society in social innovation processes here is lower than average.
\end{abstract}

Keywords: Social innovation, involvement in social innovation, financial involvement, informative involvement, organisational involvement, stakeholders in social innovation, Latvia

Reference to this paper should be made as follows: Oganisjana, K., Surikova, S., Kozlovskis, K., \& Svirina, A. (2018). Financial, organisational and informative involvement of the society in social innovation processes in Latvia, Entrepreneurship and Sustainability Issues, 6(1): 456-471. http://doi.org/10.9770/jesi.2018.6.1(28)

JEL Classifications: $\mathrm{O} 35$

\section{Introduction}

\footnotetext{
* The research is conducted within the project 5.2.7. "Involvement of the society in social innovation for providing sustainable development of Latvia" as part of the National Research Program 5.2. "Economic Transformation, Smart Growth, Governance and Legal Framework for the State and Society for Sustainable Development - a New Approach to the Creation of a Sustainable Learning Community (EKOSOC-LV)”.
} 
The International Journal

ENTREPRENEURSHIP AND SUSTAINABILITY ISSUES

ISSN 2345-0282 (online) http://jssidoi.org/jesi/

2018 Volume 6 Number 1 (September)

http://doi.org/10.9770/jesi.2018.6.1(28)

Social innovation is argued to be a tool for handling major societal challenges mobilising local actors, providing new and more efficient answers to meet growing social needs, achieving faster economic growth and enhancing productivity of public services. Social innovation is capable of integrating various stakeholders to tackle topical challenges jointly, through new ways of working together and involving users, exploiting fewer resources and creating important improvements at relatively low cost (European Commission, 2013; European Union, 2012a, 2012 b). Being a relatively new concept in Latvia, social innovation needs thorough research in order to reveal the theoretical and practical basis for its development and scaling in the Latvian reality provoking the society and making social innovation a regular practice. Therefore, the project "Involvement of the society in social innovation for providing sustainable development of Latvia" was carried out within the National Research Program 5.2. "Economic Transformation, Smart Growth, Governance and Legal Framework for the State and Society for Sustainable Development - a New Approach to the Creation of a Sustainable Learning Community (EKOSOC-LV)". The papers already published in different stages of this project provide an insight into: the interdisciplinary research approach realized by the research team from the integrated perspective of economics, management and education (Oganisjana, Surikova \& Grīnberga-Zālīte, 2016); the barriers to social innovation and ways of overcoming them in Latvia (Oganisjana, Eremina, Gvatua, Kabwende \& Chukwu, 2017); how to engage universities in social innovation research (Oganisjana, Svirina, Surikova, Grīnberga-Zālīte \& Kozlovskis, 2017); scenarios for promotion of social innovation in Latvia (Dobele, Grinberga-Zalite \& Kelle, 2015); the role of social innovation in the promotion of sustainable development of the contemporary Latvian society (Oganisjana \& Surikova, 2015); the factors influencing social innovation processes in Latvia (Oganisjana, Surikova, \& Laizāns, 2015); the role of education in promoting social innovation processes in the society (Surikova, Oganisjana \& Grinberga-Zalite, 2015), etc. This part of the research has revealed three dimensions of support and involvement of the society in social innovation processes. That has brought to the understanding of the necessity to introduce indices of financial, informative and organisational involvement of stakeholders in social innovation processes. The paper presents the approach which was elaborated and applied to define these indices together with the methodology worked out for determining them. Based on the interviews of social innovation projects, not only indices of financial, informative and organisational involvement of stakeholders were determined for the Latvian context, but also an aggregated index was calculated integrating all these dimensions in one and giving insight into the overall involvement of the society in social innovation processes.

The purpose of the research is to elaborate methodology for determining financial, organisational and informative involvement of the society in social innovation processes and applying that to the Latvian context.

Research questions:

1. Who are the stakeholders in social innovation?

2. How to evaluate stakeholders' financial, organisational and informative involvement in the realisation of social innovation projects?

What is the level of the society's financial, organisational, informative and overall involvement in social innovation processes in Latvia?

\section{The theoretical framework of the research}

In the European Commission's "Guide to social innovation", it is argued that social innovation typically goes through stages starting as ideas, which may then be piloted or prototyped for being implemented as a new venture or as a new policy within an existing institution and scaled up in the final stage, making a real impact and becoming part of the norm (European Commission, 2013). The spiral model of social innovation shows its four stages: 
1) ideas;

2) prototyping or piloting;

3) implementation;

4) scaling (European Commission, 2013: 9)

Based on the literature analysis, the project team have come to the conclusion that the starting point of social innovation is not just an idea but rather an urgent social problem which either hasn't been solved yet or is solved partly or not very effectively (Phills, Deiglmeier \& Miller, 2008; OECD, 2010; Dover, 2011; Minks, 2011; Mahmuda, Baskaran \& Pancholi, 2014; Howaldt et al., 2014, etc.). The research team defines social innovation as better, more efficient and effective solutions of social problems (Phills, Deiglmeier \& Miller, 2008; Howaldt \& Schwarz, 2010; Minks, 2011; Cajaiba-Santana, 2013; Klievink \& Janssen, 2014). In the result of social innovation, new sustainable social practices and culture including new organisations, new policy, new technological solutions, value system, mentality, etc. could be created (Howaldt \& Schwarz, 2010, The Young Foundation, 2012a; Lundstrom \& Zhou, 2011; Davies, 2014; Howaldt et al., 2014).

The specific aspect about social innovation is co-organisation and co-thinking of the stakeholders for diagnosing the social problems in the local community or in the country with further prioritization for finalizing the problem to be solved (The Young Foundation, 2012a, 2012b; Davies \& Simon, 2012). The process of social innovation has been pursued at three levels:

- delegating the role of generating social innovation to individual entrepreneur (micro),

- through the public/private partnerships (meso),

- innovating the patterns of social interaction by governments and institutions for generating social value through policies, laws, and institutional reforms (macro) (Bonifacio, 2014).

In the stage of the solution of the social problem the parties involved co-create best solutions via ideation, prototyping and piloting. In the course of implementation, the solution is improved or pivoted for achieving selfsustainability. Then the new practice is expanded and developed on, sometimes being replicated in one or more locations involving more people in social innovation processes (Murray, Caulier-Grice \& Mulgan, 2010; The Young Foundation, 2012a, 2012b).

Therefore, the research logic and the elaboration of the materials for interviewing social innovation projects in Latvia were based on the following four stages:

1) community diagnosis of social problems and prioritization of the most urgent problem;

2) co-creation including ideation and prototyping of the most effective solution for the social problem;

3) implementation of the project;

4) scaling up of the new social practice and involving broader society in the social innovation processes.

\subsection{The stakeholders of social innovation}

Scientific literature focuses on different stakeholders in social innovation research depending on the peculiarities of the projects and the key problems solved. The understanding who are the stakeholders is a complex task as social innovation is concerned with the action of different sectors, overlapping spaces between them and interacting at the interfaces among all the sectors (European Union, 2012b; Davies \& Simon, 2013a; Alegre \& Berbegal-Mirabent, 2016). Different approaches emphasize various aspects of social innovation such as: the goals, models, tools, problems solved, outcomes and the main actors. The analysis revealed the following stakeholders in social innovation:

- social innovators, i.e. individuals or legal entities who bring together ideas, resources and tools for initiating and realising social innovation projects (European Union, 2012b; Lee, 2017; Seyfang \& Smith, 2007);

- family and friends of social innovators (European Union, 2012b; Altuna, Contri, Dell'Era, Frattini \& Maccarrone, 2015; Alegre \& Berbegal-Mirabent, 2016); 


\section{The International Journal}

ENTREPRENEURSHIP AND SUSTAINABILITY ISSUES

ISSN 2345-0282 (online) http://jssidoi.org/jesi/

2018 Volume 6 Number 1 (September)

http://doi.org/10.9770/jesi.2018.6.1(28)

- other individuals who do not belong to family and friends of social innovators (Hernandez \& Cormican, 2016; Altuna et al., 2015; Lee, 2017);

- target groups, i.e. persons who gain from social innovation projects (Bund, Gerhard, Hoelscher \& Mildenberger, 2015);

- public institutions or organisations (Russon Gilman, 2017; Benneworth \& Cunha, 2015; European Union, 2012b; Alegre \& Berbegal-Mirabent, 2016; Altuna, Contri, Dell'Era, Frattini \& Maccarrone, 2015);

- municipal institutions or organisations (Alegre \& Berbegal-Mirabent, 2016; Bund, Gerhard, Hoelscher, \& Mildenberger, 2015; Lee, 2017; Seyfang \& Smith, 2007);

- enterprises (Hernandez \& Cormican, 2016; Benneworth \& Cunha, 2015; European Union, 2012b; Altuna et al., 2015; Alegre \& Berbegal-Mirabent, 2016; Lee, 2017);

- $\quad$ non-governmental organisations (Altuna et al., 2015; Alegre \& Berbegal-Mirabent, 2016; Seyfang \& Smith, 2007);

- educational institutions (Benneworth \& Cunha, 2015; Altuna et al., 2015);

- supranational institutions or organisations of the European Union (European Union, 2012b; Bund et al., 2015).

This classification of the stakeholders served as a basis for the elaboration of the interview materials and creation of the system for the evaluation of stakeholders' involvement in social innovation processes.

\subsection{Financial, informative and organisational involvement in social innovation}

Society's involvement in social innovation refers to providing 1) information and resources, 2) problem solving and 3) taking and influencing decisions (Davies \& Simon, 2013b). The involvement of the stakeholders in social innovation processes was revealed to be related to financial, organisational and informative dimensions of their support in the realisation of creative solutions in society's life.

Financial involvement of stakeholders. Social innovation is supported by European Structural funds (comprising the European Social Fund and the European Regional Development Fund) and Cohesion Fund to promote policies, programmes and initiatives and empower citizens and organisations to address social issues. Other sources of social innovation funding are Social banks, Commercial investment funds, Social investment funds and Venture philanthropy funds (European Union, 2012b). However, also crowdsourcing can be one of the types of funding of social innovation (Davies \& Simon, 2013b); that is conditioned by its bottom-up nature and participation in it broad layers of society. A significant role in funding social innovation is played by municipalities as projects initiated by local authorities enable more long-term measures and can be better adjusted to local needs; therefore, municipalities have been admitted to be crucial initiators and driving actors of sustainable social innovation (Bund, Gerhard, Hoelscher \& Mildenberger, 2015). Municipalities oversee social innovation programs and work on legislation securing funds from either government budgets or social financing (Lee, 2017). Financial support is provided also by universities which invest in activities which contribute to testing or upscaling social innovation and delivering innovative services (Benneworth \& Cunha, 2015).

Informative involvement of stakeholders. Engagement of citizens in social innovation is often necessary to understand and uncover complex needs or gather ideas for new and better solutions; citizens themselves are best placed to articulate the nature of the challenges they face often becoming the source of innovative ideas (Davies \& Simon, 2013b). Universities play the role of knowledge provider informing the society about the existing knowledge or creating new knowledge, as well as working with social partners to co-create new knowledge which contributes to social innovation; universities also provide advice to social innovators on how best to access external knowledge resources or who might be able to help them (Benneworth \& Cunha, 2015: 518). Most powerful information providing aspect of social innovation is related to social networks which realise various 
The International Journal

ENTREPRENEURSHIP AND SUSTAINABILITY ISSUES

ISSN 2345-0282 (online) http://jssidoi.org/jesi/

2018 Volume 6 Number 1 (September)

http://doi.org/10.9770/jesi.2018.6.1(28)

online-based activities, proactively leading and disseminating public opinion via utilizing new platforms for dialogue and knowledge sharing in rapidly expanding online communities (Lee, 2017).

Organisational involvement of stakeholders. According to Davis and Simon (2013b), society provides organisational support to social innovation in multiple ways in different stages of its realisation: in early stages developing a better understanding of needs or gathering ideas for new and better solutions, and in later stages solving problems via co-designing processes and taking and influencing decisions. A crucial organisational role is played by municipalities which establish intermediary organisations and networks for facilitating collaboration between governments and companies, as well as support local social innovators and adopt social innovation projects to foster local self-reliance, leading to the revitalization of local economies and communities (Lee, 2017). Organisational support to social innovation is rendered also by educational institutions; universities make their premises including offices, libraries and laboratories, available during social innovation processes and help to persuade third parties of the value of the social innovation and help them to adopt or invest their resources in the social innovation (Benneworth \& Cunha, 2015: 518).

Based on these judgements, the empirical part of the research conducted within the project "Involvement of the society in social innovation for providing sustainable development of Latvia" was carried out for these three dimensions - financial, informative and organisational involvement of the ten groups of stakeholders in social innovation processes.

\section{Research methodology}

The research design was elaborated according to the four stages of social innovation analysed above. The data were collected in 2016-2017 within face-to-face or online interviews of social innovation projects in Latvia which were in different phases of their development. The empirical part of the research focuses on the following major stakeholders who participate in social innovation processes:

- social innovator $(S I)$;

- family and friends of social innovators $(F F)$;

- other individuals (IND);

- $\quad$ target group $(T G)$;

- public institutions $(P I)$;

- municipal institutions $(M I)$;

- enterprises $(E)$;

- non-governmental organisations $(N G O)$;

- educational institutions $(E D U)$;

- European Union institutions $(E U)$.

The three dimensions of the involvement of the stakeholders in social innovation processes are defined by the authors as follows:

- financial involvement (FINI) - any investment from any stakeholder to finance the processes related to the initiation and implementation of social innovation in real life;

- informative involvement (INFI) - any informative support, idea and advice from any stakeholder for raising awareness, sharing and spreading information which could help in the realization of social innovation;

- organisational involvement (ORGI) - any effort, care, lobbying, work, guidance, monitoring of performance and contribution into the realization of events and activities for achieving the objectives in any stage of the elaboration and realization of social innovation. 
The involvement of the society in social innovation processes is estimated for the stakeholders using a 10 -score valuation system, where " 0 " means "no involvement" and "10" - "full involvement". These data were collected while interviewing representatives of 115 social innovation projects - social innovators; they had to estimate the level of their own and the other stakeholders' financial, informative and organisational involvement in the realization of their projects. The scores were organized in a special matrix for each respondent separately as shown in the template (see Table 1).

Table 1. Matrix of scores of financial, informative and organisational involvement in social innovation processes (template)

\begin{tabular}{|c|c|c|c|c|c|c|c|c|c|c|c|}
\hline & & \multicolumn{10}{|c|}{ Stakeholders } \\
\hline & & SI & TG & PI & MI & $\mathbf{E}$ & FF & IND & NGO & EDU & $\mathbf{E U}$ \\
\hline \multirow{3}{*}{ 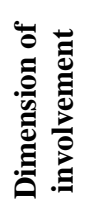 } & FINI & $f_{1}$ & $f_{2}$ & $f_{3}$ & $f_{4}$ & $f_{5}$ & $f_{6}$ & $f_{7}$ & $f_{8}$ & $f_{9}$ & $f_{10}$ \\
\hline & INFI & $i_{1}$ & $i_{2}$ & $i_{3}$ & $i_{4}$ & $i_{5}$ & $i_{6}$ & $i_{7}$ & $i_{8}$ & $i_{9}$ & $i_{10}$ \\
\hline & ORGI & $o_{1}$ & $o_{2}$ & $o_{3}$ & $o_{4}$ & $o_{5}$ & $o_{6}$ & $o_{7}$ & $o_{8}$ & $o_{9}$ & $o_{10}$ \\
\hline
\end{tabular}

Source: the authors

The matrix of scores represents three sets of values grouped by the dimensions of involvement. Using the data from all the 115 matrices, indices of financial, informative and organisational involvement of stakeholders in social innovation processes were calculated. The idea of introducing indices of financial, informative and organisational involvement in social innovation processes was elaborated based on the logic and approach of calculating different macroeconomic indicators such as: Purchasing Managers' Index represented by the Institute for Supply Management (Institute for Supply Management, 2016) and German Ifo Business Climate Index introduced by Center for Economic Studies of Leibniz Institute for Economic Research at the University of Munich (CESifo Group Munich, 2016). The indices of involvement of stakeholders in social innovation processes were calculated using the following formulas:

$$
\begin{aligned}
& \text { Index }_{\text {FINI }}=\frac{1}{n z} \sum_{j=1}^{n} \sum_{i=1}^{z} f_{i, j} \\
& \text { Index }_{\text {INFI }}=\frac{1}{n z} \sum_{j=1}^{n} \sum_{i=1}^{z} i_{i, j} \\
& \text { Index }_{\text {ORGI }}=\frac{1}{n z} \sum_{j=1}^{n} \sum_{i=1}^{z} o_{i, j}
\end{aligned}
$$

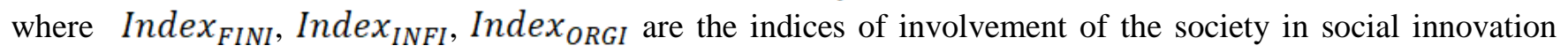
processes related accordingly to financial, informative and organisational involvement of stakeholders;

$n$ - total number of interviewees $(n=115)$;

$z$-total number of the stakeholders $(z=10)$.

Each $s^{\text {th }}$ stakeholder's involvement can be estimated based on the formula:

$$
\text { Index }_{s}=\frac{1}{3 n} \sum_{i=1}^{n}\left(f_{s, i}+i_{s, i}+o_{s, i}\right)
$$


To estimate the total involvement of the society in social innovation processes in Latvia taking into account the involvement of all the stakeholders in all the three dimensions of involvement, the authors suggest calculating an aggregate index (AIndex) represented by the grand mean shown in the following composite formula:

$$
\text { AIndex }=\frac{1}{n p z} \sum_{m=1}^{n} \sum_{j=1}^{p} \sum_{i=1}^{z} \operatorname{score}_{j, i}^{m}
$$

where $p$-total number of the dimensions of involvement $(p=3)$.

This aggregated index can be developed on in case if new categories of involvement such as: size of project, industry or sector of economy, geographical characteristics, etc. are needed to be considered.

\section{The characteristics of the research sample and context}

As social innovation is a newly developing reality in the Latvian society, it was a real challenge to seek out appropriate projects according to the criteria of the concept of the theory-based understanding of what social innovation is. The 115 social innovation projects (social innovators) were interviewed in the period of time from October, 2016 to April, 2017.

The projects were in different stages of their development. Some of them (28.7\%) had already finished their activities by the time of the interview. There were also starters $(3.5 \%)$ who hadn't functioned even for one full year (Table 2).

Table 2. The duration of the projects by the time of the interview

\begin{tabular}{|c|c|c|c|c|c|c|c|c|c|c|c|c|c|c|c|}
\hline $\begin{array}{c}\text { Duration of the } \\
\text { project (full years) }\end{array}$ & 0 & 1 & 2 & 3 & 4 & 5 & 6 & 7 & 8 & 9 & 10 & 11 & 13 & 14 & 19 \\
\hline Number of projects & 4 & 25 & 24 & 16 & 12 & 6 & 5 & 8 & 3 & 5 & 1 & 3 & 1 & 1 & 1 \\
\hline Percent $(\%)$ & 3.5 & 21.7 & 20.9 & 13.9 & 10.4 & 5.2 & 4.3 & 0.9 & 2.6 & 4.3 & 0.9 & 2.6 & 0.9 & 0.9 & 0.9 \\
\hline
\end{tabular}

\section{Source: the authors}

The duration of the main body of the projects varied mainly from one year $(21.7 \%)$ to four years $(10.4 \%)$. However, $5.3 \%$ of the projects were with lifespan bigger than 10 years (see Table 2).

Spread over all the regions of Latvia, the social innovation projects represented mainly NGO (47.8\%), enterprises $(18.3 \%)$ and municipal institutions or organisations (15.7\%). Social innovators from educational institutions (2.6\%), public institutions or organisations (1.7\%) and individuals $(0.9 \%)$ were rarer than the other project holders which might indirectly speak of their being less active in social innovation processes in Latvia.

The distinct majority $(55.7 \%)$ of the social innovation projects employed less than 10 people $(\mathrm{n}<10)$, small sized projects $(\mathrm{n}<50)-26.1 \%$, medium sized projects $(\mathrm{n}<250)-9.6 \%$ and big projects $(\mathrm{n}>250)-8.7 \%$ of the projects interviewed.

The projects covered a broad range of fields of activities: education (42.6\%), tourism, entertainment and leisure (24.3\%), social care (14.8\%), environment and ecology (14.8\%), health care (13.8\%), sports (9.6\%), charity 
The International Journal

ENTREPRENEURSHIP AND SUSTAINABILITY ISSUES

ISSN 2345-0282 (online) http://jssidoi.org/jesi/

2018 Volume 6 Number 1 (September)

http://doi.org/10.9770/jesi.2018.6.1(28)

(8.7\%), culture and arts (7.8\%), ICT and other technologies (4.3\%), manufacturing (3.5\%), agriculture (1.7\%) and other fields (11.3\%). Some projects dealt with complex activities integrating two or three fields in one or overlapping some fields; in such cases social innovation projects were offered to indicate more than one field. That is the reason why, the sum of the percent of all the fields mentioned exceeds $100 \%$.

The target groups of the interviewed social innovation projects were: children and youngsters (53.9\%), people with special needs (27.8\%), seniors (27.0\%), families with many children (24.3\%), unemployed people (15.7\%) and others $(55.7 \%)$. As some of the projects had multiple target groups, they mentioned more than one option; therefore, the sum of the overall percent is more than $100 \%$.

Out of the 115 interviewees 78 projects $(67.8 \%)$ stated that they had volunteers engaged in the projects. Bigger part of the respondents $(59.1 \%)$ said that they had started their projects in order to solve some topical and urgent problems of their families, friends, local communities and the society as a whole, while only $21.7 \%$ of the respondents had identified some interesting ideas which motivated them to start the social innovation projects. The remaining $19.1 \%$ indicated some other reasons.

The main barriers to social innovation were pointed out to be: lack of financing (39.1\%); passivity in the society (31.3\%); administrative and bureaucratic barriers (31.3\%); lack of openness of the society to other people's experience and collaboration (14.8\%); the absence of public policy and legal framework for social innovation (13\%); passivity and low level of support from stakeholders (12.2\%); lack of experience in realizing social innovation projects (11.3\%); lack of access to information needed (11.3\%) and other barriers (18.3\%). Only $12.2 \%$ of the respondents considered that they didn't have any hindrances in the realization of their projects. As some projects spoke of more than one barrier, the sum of the percent of all the barriers is more than $100 \%$.

Having analysed the course and the style of the solution of the main problem, the respondents concluded that the problem had been solved: by the project group on their own $(23.5 \%)$; in the active collaboration of all the stakeholders including the project group, external individuals and/or organisations and the target group (20.9\%); by the project group in collaboration with the target group $(14.8 \%)$; based on the collaboration of the project group with external individuals and/or organisations (12.2\%); by the target group themselves under the facilitation of the project group (4.3\%) and in another way $(6.1 \%)$.

Analysing whether their projects were financially self-sustainable, $36.5 \%$ of the respondents replied positively, $37.4 \%$ considered that they were financially self-sustainable partly, $16.5 \%$ said they weren't and $9.6 \%$ gave other answers.

The answers to the question asked with the aim to spread light on the situation with scaling social innovation practices in Latvia, revealed that: $11.3 \%$ of the social innovation projects had been replicated at the level of the city / district, $2.6 \%$ - at the level of the region, $18.3 \%$ - at the national level and $18.3 \%$ - internationally. However, $17.4 \%$ replied that the project hadn't been scaled. Almost one third of the respondents (32.2\%) were not aware of the further development of their practices.

The majority of the projects interviewed $(90.4 \%)$ is planning to continue the realisation of their social innovation ideas, while $9.6 \%$ don't have such an intention.

\section{Findings of the research}

The dynamics of involvement of the society in social innovation processes in Latvia characterized by the three indices of financial, informative and organisational involvement of the stakeholders (see Figure 1) were constructed based on the calculations according to formulas (1), (2) and (3). 


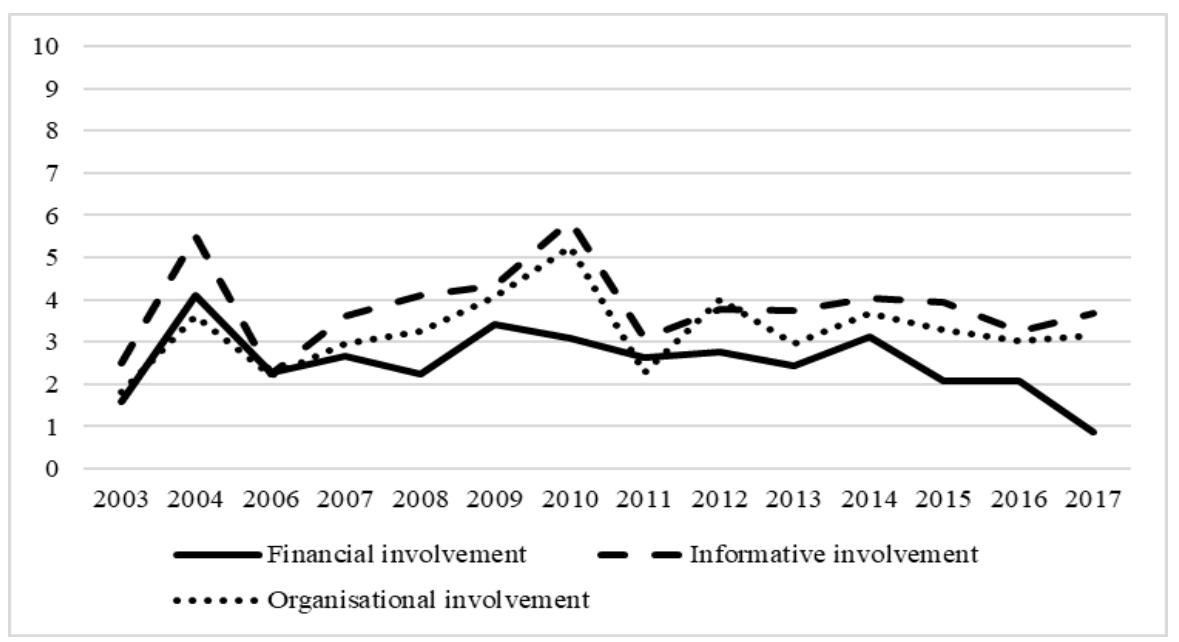

Figure 1. Dynamics of involvement of the society in social innovation processes in Latvia characterized by indices of financial, informative and organisational involvement

Source: the authors

As seen in Figure 1, informative and organisational involvements quite highly correlate with each other while financial involvement has a downtrend over the years. This tendency is revealed also in the calculation of correlation coefficients shown in the matrix in Table 3.

Table 3. Correlation matrix of financial, informative and organisational involvement in social innovation

\begin{tabular}{|l|c|c|c|}
\hline & $\begin{array}{c}\text { Financial } \\
\text { involvement }\end{array}$ & $\begin{array}{c}\text { Informative } \\
\text { involvement }\end{array}$ & $\begin{array}{c}\text { Organisational } \\
\text { involvement }\end{array}$ \\
\hline Financial involvement & 1 & & \\
\hline Informative involvement & 0.62 & 1 & 1 \\
\hline Organisational involvement & 0.51 & 0.86 & \\
\hline
\end{tabular}

Source: the authors

Analysing the values of indices (see Figure 1), it can be concluded that the Latvian society does not have high level of involvement in social innovation processes:

- financial involvement index $0.88<\operatorname{Index}_{F I N I}<4.10$;

- informative involvement index $2.25<$ Index $_{I N F I}<5.87$;

- organisational involvement index $1.80<$ Index $_{O R G I}<5.23$.

Thus, the stakeholders participated in social innovation processes having more informative and organisational involvement rather than financial involvement $\left(\right.$ Index $_{F I N I}<$ Index $_{O R G I}<$ Index $\left._{I N F I}\right)$.

In the context of involvement of the stakeholders in social innovation processes in Latvia there is one leader social innovators themselves. That means social innovators use or create their own sources of finance (see Figure 2), provide most informative base to other stakeholders (see Figure 3) and carry out the main organisational activities (see Figure 4). 


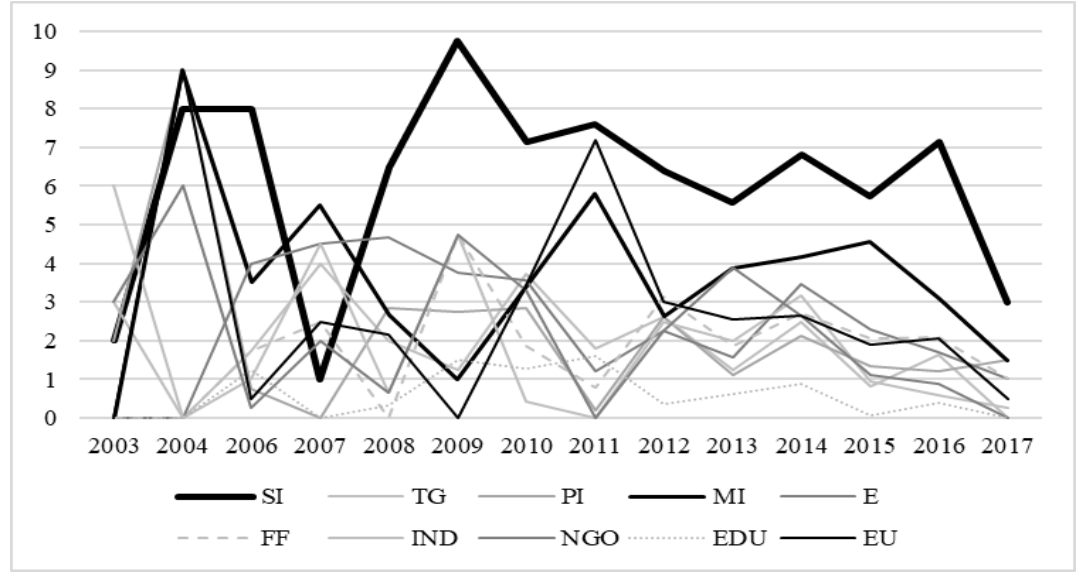

Figure 2. Dynamics of financial involvement of the stakeholders in social innovation processes

Source: the authors

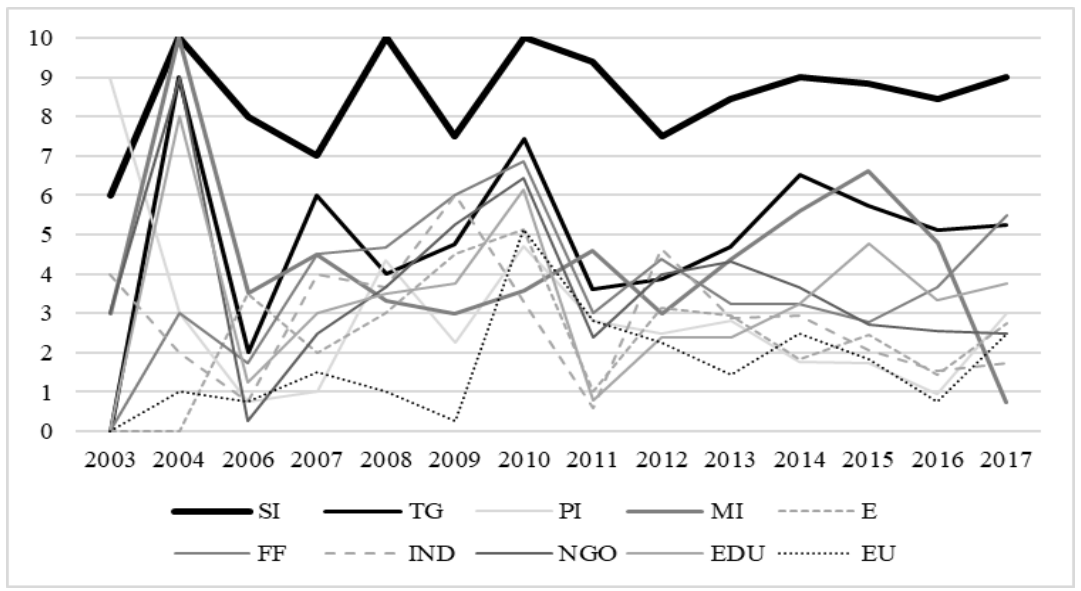

Figure 3. Dynamics of informative involvement of the stakeholders in social innovation processes Source: the authors 


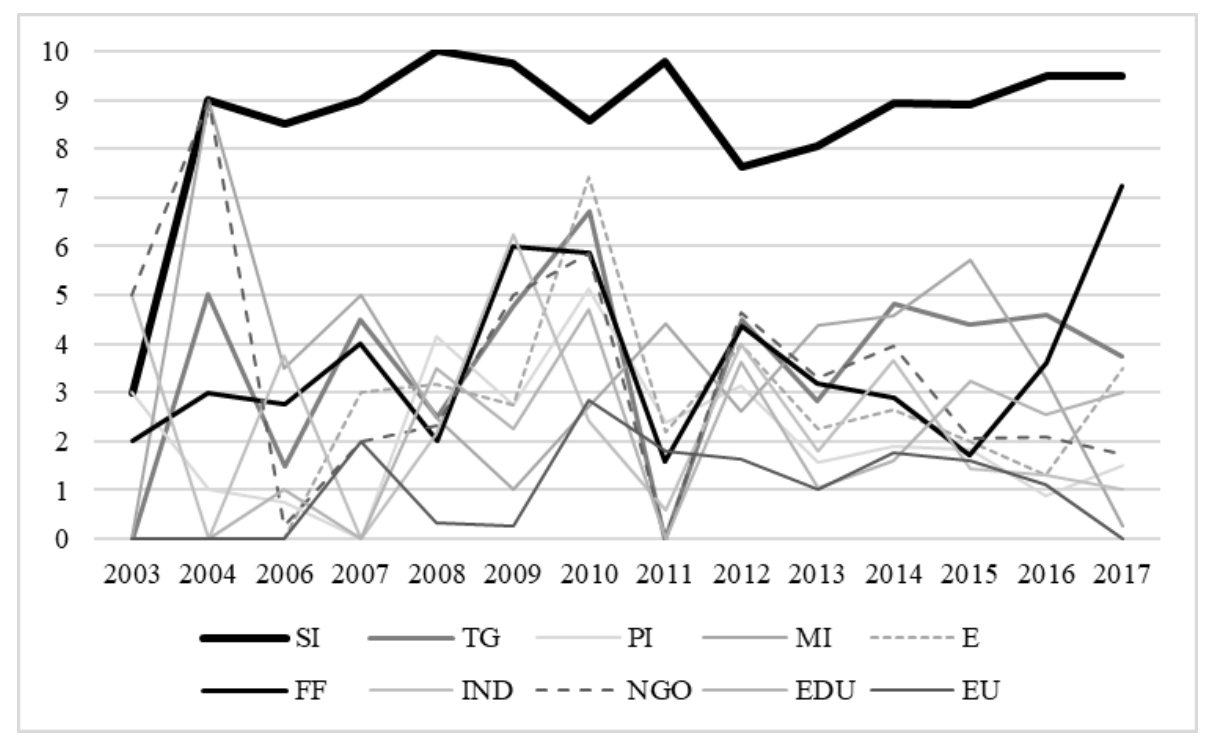

Figure 4. Dynamics of organisational involvement of the stakeholders in social innovation processes

The more detailed analysis shows that the average indices of financial (Index $\operatorname{FINI}_{\text {SI }}=6.04$ ), informative $\left(\right.$ Index $\left._{I N F I}^{S I}=8.51\right)$ and organisational $\left(\right.$ Index ORGI $\left._{\text {SI }}=8.58\right)$ involvement of social innovators are significantly higher compared with the other stakeholders (see Table 4).

Table 4. The indices of involvement of the stakeholders in social innovation processes averaged over the period of 2003-2017

\begin{tabular}{|c|c|c|c|c|c|c|}
\hline \multirow{2}{*}{ Rank } & \multicolumn{2}{|c|}{ Financial involvement } & \multicolumn{2}{|c|}{ Informative involvement } & \multicolumn{2}{|c|}{ Organisational involvement } \\
\hline & stakeholder & Index $x_{F I N I}$ & stakeholder & Index $x_{I N F I}$ & stakeholder & Index $x_{O R G I}$ \\
\hline 1 & SI & 6.04 & SI & 8.51 & SI & 8.58 \\
\hline 2 & MI & 3.62 & TG & 4.85 & FF & 3.59 \\
\hline 3 & $\mathbf{E U}$ & 2.67 & MI & 4.33 & TG & 3.56 \\
\hline 4 & $\mathrm{E}$ & 2.42 & $\mathrm{FF}$ & 3.75 & MI & 3.50 \\
\hline 5 & NGO & 2.20 & NGO & 3.73 & NGO & 3.37 \\
\hline 6 & PI & 2.16 & EDU & 3.31 & $\mathrm{E}$ & 2.45 \\
\hline 7 & IND & 1.92 & PI & 2.90 & IND & 2.39 \\
\hline 8 & TG & 1.88 & IND & 2.86 & PI & 2.14 \\
\hline 9 & $\mathrm{FF}$ & 1.75 & $\mathrm{E}$ & 2.41 & EDU & 1.89 \\
\hline 10 & EDU & 0.59 & $\mathrm{EU}$ & 1.69 & EU & 1.02 \\
\hline
\end{tabular}

Source: the authors

However, among the other stakeholders, municipalities demonstrate most openness and readiness to support social innovators financially $\left(\operatorname{Index}_{F I N I}^{M I}=3.62\right)$; in some cases, financial support is rendered also by some 
European Union organisations (Index $x_{F I N I}^{E U}=2.67$ ). The index of financial involvement of the other stakeholders is less than 2.5 .

Besides the social innovators, also the target group $\left(\operatorname{Index}_{I N F I}^{T G}=4.85\right)$ and municipalities $\left(\right.$ Index $x_{I N F I}^{M I}=$ 4.33) have informative involvement in social innovation processes which can be explained by their direct interest in the outcomes.

Organisational involvement is actively provided by social innovators who exploit their own skills and resources $\left(I n d e x_{O R G I}^{S I}=8.58\right)$ combining efforts with their families and friends $\left(I n d e x_{O R G I}^{F F}=3.59\right)$ and the target group $\left(\right.$ Index $x_{O R G I}^{T G}=3.56$ ). However, an active role is played also by municipalities $\left(\right.$ Index $X_{O R G I}^{M I}=3.50$ ).

Having determined the aggregated index of involvement of the society in social innovation processes in Latvia for each year separately (2003-2017) and the grand mean (3.20) over this period, it is concluded that the Latvian society is quite passive (see in Figure 5).

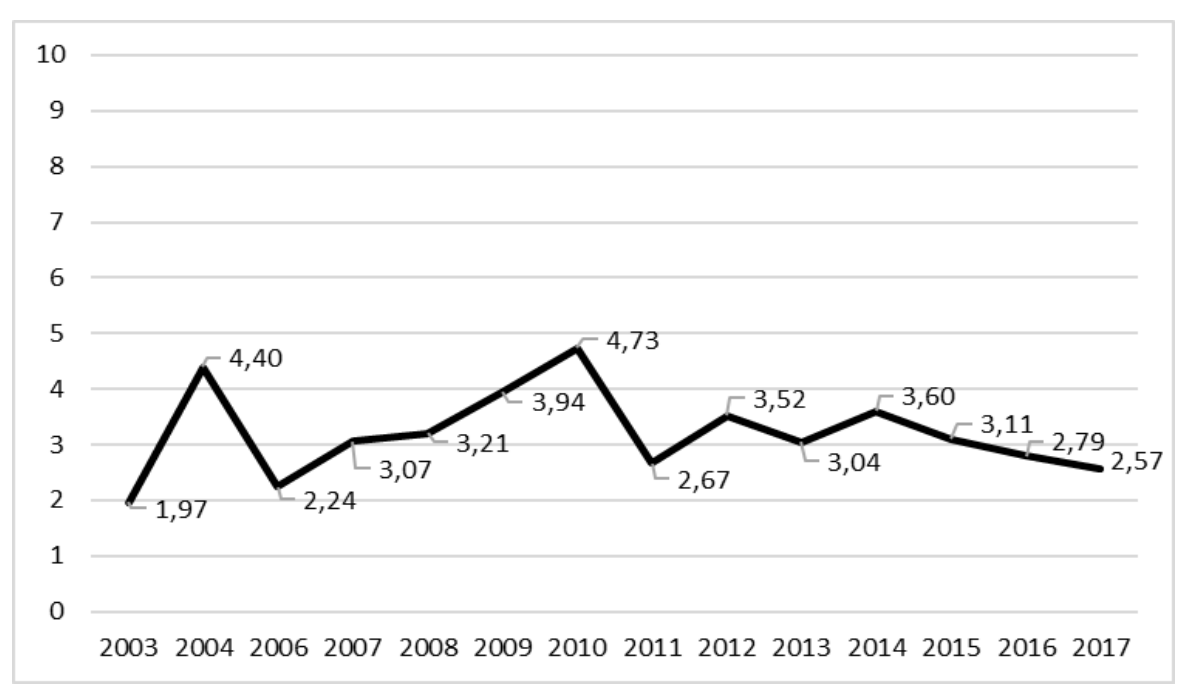

Figure 5. Aggregated index of involvement of the society in social innovation processes in Latvia

Source: the authors

\section{Conclusions}

Social innovation is realized by ten major groups of stakeholders: social innovators, their family and friends; other individuals who do not belong to family and friends of social innovators, target groups, public institutions or organisations, municipal institutions or organisations, enterprises, non-governmental organisations, educational institutions and supranational institutions or organisations of the European Union.

Stakeholders' financial, organisational and informative involvement in the realisation of social innovation can be evaluated based on the authors' elaborated indices - the means of the of social innovators' evaluations of the stakeholders' inputs in 10-point systems (see formulas 1-3).

The level of the society's financial, organisational, informative and overall involvement in social innovation processes in Latvia is not high which can be conditioned by the fact that social innovation is a relatively new concept in the Latvian society and there is not even a legal framework for that yet. Social innovators here try to solve their problems faced on their own account: 1) for organisational purposes attracting help of families and friends as well as of the target groups; 2) for getting information using the sources provided mainly by the target 
groups, municipalities and families and friends; 3) for getting financial resources seeking for local municipalities' support and the European funds. The level of involvement of each stakeholder, excluding social innovators themselves, is rather low (see Table 4). Besides the social innovators, also municipal institutions and organisations in Latvia take an active part in the realisation of social innovation at informative, organisational and financial levels as they are directly interested in solving urgent problems and causing positive changes in the local community's life and environment.

\section{References}

Alegre, I.; \& Berbegal-Mirabent, J. 2016. Social innovation success factors: hospitality and tourism social enterprises, International Journal of Contemporary Hospitality Management, 28(6): 1155-1176. https://doi.org/10.1108/IJCHM-05-2014-0231

Altuna, N.; Contri, A.M.; Dell'Era, C.; Frattini, F.; \& Maccarrone, P. 2015. Managing social innovation in for-profit organisations: the case of Intesa Sanpaolo, European Journal of Innovation Management, 18(2): 258-280. https://doi.org/10.1108/EJIM-06-2014-0058

Benneworth, P.; \& Cunha, J. 2015. Universities' contributions to social innovation: reflections in theory and practice, European Journal of Innovation Management, 18(4): 508-527. https://doi.org/10.1108/EJIM-10-2013-0099

Bonifacio, M. 2014. Social Innovation: a Novel Policy Stream or a Policy Compromise? An EU Perspective, European Review, 22(1): 145169. https://doi.org/10.1017/S1062798713000707

Bund, E.; Gerhard, U.; Hoelscher, M.; \& Mildenberger, G. 2015. A methodological framework for measuring social innovation, Historical Social Research / Historische Sozialforschung, Special Issue: Methods of Innovation Research: Qualitative, Quantitative and Mixed Methods Approaches, 40(3/153): 48-78.

Cajaiba-Santana, G. 2013. Social innovation: Moving the field forward. A conceptual framework, Technological Forecasting and Social Change, 82: 42-51. https://doi.org/10.1016/j.techfore.2013.05.008

CESifo Group Munich. 2016. Design and Methodology of the Ifo Business Survey in the German Services Sector. Retrieved from https://www.cesifo-group.de/ifoHome/facts/Survey-Results/Konjunkturtest/Dienstleistungen/Aufbau-und-Methodik-des-ifo$\underline{\text { Konjunkturtest-Dienstleistungen-Deutschland--.html }}$

Davies, A.; \& Simon, J. 2013a. The value and role of citizen engagement in social innovation. A deliverable of the project: "The theoretical, empirical and policy foundations for building social innovation in Europe" (TEPSIE), European Commission - 7th Framework

Programme, Brussels: European Commission, DG Research. Retrieved from https://youngfoundation.org/wp-

content/uploads/2013/11/value-and-role-of-citizen-engagement.pdf

Davies, A.; \& Simon, J. 2013b. Engaging Citizens in Social Innovation: A short guide to the research for policy makers and practitioners. A deliverable of the project: "The theoretical, empirical and policy foundations for building social innovation in Europe" (TEPSIE), European Commission - 7th Framework Programme, Brussels: European Commission, DG Research. Retrieved from https://youngfoundation.org/wp-content/uploads/2013/11/Engagign-citizens-in-social-inno.pdf

Davies, A.; \& Simon, J. 2012. Citizen engagement in social innovation - a case study report. A deliverable of the project: "The theoretical, empirical and policy foundations for building social innovation in Europe" (TEPSIE), European Commission - 7th Framework Programme, Brussels: European Commission, DG Research. Retrieved from https://youngfoundation.org/wpcontent/uploads/2013/11/citizen-engage-in-soc-inno.pdf

Davies, A. 2014. Spreading Social Innovations: A Case Study Report. A deliverable of the project: “The theoretical, empirical and policy foundations for building social innovation in Europe" (TEPSIE), European Commission - 7th Framework Programme, Brussels: European Commission, DG Research. Retrieved from https://educationinnovations.org/sites/default/files/Spreading\%20Social\%20Innovations\%20\%E2\%80\%93\%20A\%20Case\%20Study\%20R eport.pdf 
The International Journal

ISSN 2345-0282 (online) http://jssidoi.org/jesi/

2018 Volume 6 Number 1 (September)

http://doi.org/10.9770/jesi.2018.6.1(28)

Dobele, L.; Grinberga-Zalite, G.; Kelle, L. 2015. Sustainable economic development: scenarios for promotion of social innovation in Latvia, Journal of Security and Sustainability Issues, 5(2): 149-158. https://doi.org/10.9770/jssi.2015.5.2(2)

Dover, G. 2011. Social Innovation and Institutional Work: A Study of the Role of Place and Place-Making in Social Innovations for the "Hard-to-House". Dissertation submitted in partial fulfillment of the requirements for the degree of doctor of philosophy in the Faculty of Business Administration.

European Commission. 2013. Guide to social innovation. Regional and Urban Policy. Retrieved from http://s3platform.jrc.ec.europa.eu/documents/20182/84453/Guide_to_Social_Innovation.pdf/88aac14c-bb15-4232-88f1-24b844900a66

European Union. 2012a. Strengthening social innovation in Europe. Journey to effective assessment and metrics. Retrieved from https://publications.europa.eu/en/publication-detail/-/publication/448c51d1-6933-46b0-9c39-5ffff10cb1c1

European Union. 2012b. Financing social impact: Funding social innovation in Europe - mapping the way forward. COM, Brussels. Retrieved from https://youngfoundation.org/wp-content/uploads/2012/10/Financing-Social-Impact.pdf

Hernandez, Y.; \& Cormican, K. 2016. Towards the effective management of social innovation projects: Insights from project management, Procedia Computer Science, 100: 237-243. https://doi.org/0.1016/j.procs.2016.09.148

Howaldt, J.; Butzin, A.; Domanski, D.; \& Kaletka, C. 2014. Theoretical Approaches to Social Innovation - A Critical Literature Review. A deliverable of the project: 'Social Innovation: Driving Force of Social Change' (SI-DRIVE). Dortmund: Sozialforschungsstelle. Retrieved from http://www.si-drive.eu/wp-content/uploads/2014/11/D1_1-Critical-Literature-Review.pdf

Howaldt, J.; \& Schwarz, M. 2010. Social Innovation: Concepts, research fields and international trends. IMO international monitoring. Retrieved from http://www.asprea.org/imagenes/IMO\%20Trendstudie_Howaldt_englisch_Final\%20ds.pdf

Institute for Supply Management. (2016). ISM Report On Business. Retrieved from https://www.instituteforsupplymanagement.org/pubs/content.cfm?ItemNumber=10706\&SSO=1

Klievink, B.; \& Janssen, M. 2014. Developing Multi-Layer Information Infrastructures: Advancing Social Innovation through PublicPrivate Governance, Information Systems Management, 31(3): 240-249. https://doi.org/10.1080/10580530.2014.923268

Lee, E.K. 2017. Engaging citizens in society, Social Innovation and Social Transition in East Asia, spring: 16-18.

Lundstrom, A.; Zhou, Ch. 2011. Promoting innovation based on social sciences and technologies: the prospect of a social innovation park, Innovation: The European Journal of Social Sciences, 24(1/2): 133-149. https://doi.org/10.1080/13511610.2011.583864

Mahmuda, I.; Baskaran, A; \& Pancholi, J. 2014. Financing social innovation for poverty reduction: A case study of microfinancing and microenterprise development in Bangladesh, Science, Technology \& Society, 19(2): 249-273. https://doi.org/10.1177/0971721814529879

Minks, M. 2011. Social Innovation: New Solutions to Social Problems. A Thesis submitted to the Faculty of the School of Continuing Studies and of The Graduate School of Arts and Sciences in partial fulfillment of the requirements for the degree of Master of Arts in Liberal Studies.

Murray, R.; Caulier-Grice, J.; \& Mulgan, G. 2010. Ways to design, develop and grow social innovation: The open book of social innovation. The Young Foundation \& NESTA. Retrieved from http://youngfoundation.org/wp-content/uploads/2012/10/The-Open-Book-of-SocialInnovationg.pdf

OECD. 2010. SMEs, Entrepreneurship and Innovation. Series: OECD Studies on SMEs and Entrepreneurship. OECD Publishing.

Oganisjana, K.; Eremina Y.; Gvatua, S.; Kabwende, B.N.; \& Chukwu, O.J. 2017. Barriers to Social Innovation and Ways of Overcoming Them in Latvia, Journal on Systemics, Cybernetics and Informatics: JSCI, 15(5): 33-38. http://www.iiisci.org/journal/sci/issue.asp?is=ISS1705

Oganisjana, K.; Svirina, A.; Surikova, S.; Grīnberga-Zālīte, G.; \& Kozlovskis, K. 2017. Engaging universities in social innovation research for understanding sustainability issues, Entrepreneurship and sustainability issues, 5(1): 9-22. http://jssidoi.org/jesi/uploads/issues/Entrepreneurship_and_Sustainability_Issues_Vol5_No1_print.pdf 
The International Journal

ENTREPRENEURSHIP AND SUSTAINABILITY ISSUES

ISSN 2345-0282 (online) http://jssidoi.org/jesi/

2018 Volume 6 Number 1 (September)

http://doi.org/10.9770/jesi.2018.6.1(28)

Oganisjana, K.; Surikova, S.; \& Grīnberga-Zālīte, G. 2016. Sociālās inovācijas izpēte starpdisciplinārā skatījumā, Latvijas Zinātņu Akadēmijas Vēstis, 70(3): 68.-76.1pp.

Oganisjana, K.; \& Surikova, S. 2015. Social innovation in the promotion of sustainable development of the contemporary Latvian society, Journal of Security and Sustainability Issues, 5(2): 249-258. https://doi.org/10.9770/jssi.2015.5.2(10)

Oganisjana, K.; Surikova, S.; Laizāns, T. 2015. Factors influencing social innovation processes in Latvia, Entrepreneurship and Sustainability Issues 3(2): 186-197. https://doi.org/10.9770/jesi.2015.3.2(6)

Phills, J.A.; Deiglmeier, K.; \& Miller, D.T. 2008. Rediscovering social innovation, Stanford Social Innovation Review, 6(4): 33-43. http://ssir.org/images/articles/2008FA_feature_phills_deiglmeier_miller.pdf

Seyfang, G.; \& Smith, A., 2007. Grassroots innovations for sustainable development: towards a new research and policy agenda, Environmental Politics 16(4): 584-603.

Russon Gilman, H. (2017). The moment for participatory democracy. Stanford Social Innovation Review. Retrieved from https://ssir.org/articles/entry/the_moment_for_participatory_democracy

Surikova, S.; Oganisjana, K.; \& Grinberga-Zalite, G. 2015. The role of education in promoting social innovation processes in the society, in Lubkina, V. and Usca S. (Eds.), Society. Integration. Education. Proceedings of the International Scientific Conference, May 22nd-23rd, 2015, Vol. IV, Rēzekne: Rēzeknes Augstskola, 233-243. http://dx.doi.org/10.17770/sie2015vol4.337

The Young Foundation. 2012a. Social Innovation Overview - Part I: Defining social innovation. A deliverable of the project: "The theoretical, empirical and policy foundations for building social innovation in Europe" (TEPSIE), European Commission - 7th Framework Programme, Brussels: European Commission, DG Research. Retrieved from https://youngfoundation.org/wpcontent/uploads/2012/12/TEPSIE.D1.1.Report.DefiningSocialInnovation.Part-1-defining-social-innovation.pdf

The Young Foundation. 2012b. Social Innovation Overview - Part II: Practices and Trends. A deliverable of the project: "The theoretical, empirical and policy foundations for building social innovation in Europe" (TEPSIE), European Commission - 7th Framework Programme, Brussels: European Commission, DG Research.

\section{Acknowledgement}

The research is conducted within the project 5.2.7. "Involvement of the society in social innovation for providing sustainable development of Latvia" as part of the National Research Program 5.2. "Economic Transformation, Smart Growth, Governance and Legal Framework for the State and Society for Sustainable Development - a New Approach to the Creation of a Sustainable Learning Community (EKOSOC-LV)". 
The International Journal

ENTREPRENEURSHIP AND SUSTAINABILITY ISSUES

ISSN 2345-0282 (online) http://jssidoi.org/jesi/

2018 Volume 6 Number 1 (September)

http://doi.org/10.9770/jesi.2018.6.1(28)

Short biographical note about the contributors at the end of the article (name, surname, academic title and scientific degree, duties, research interests):

Karine OGANISJANA, Dr. paed. is an associated professor and leading researcher at the Faculty of Engineering Economics and Management of Riga Technical University. Her fields of expertise are research methods, qualitative research, pedagogy and interdisciplinary teaching and learning for developing students' creativity, entrepreneurial skills, critical, logical, analytical and systems thinking. Karine Oganisjana has been the head of a European Social Fund project and National Research Programme project. She is a member of ASEM, Asia-Europe Lifelong Learning Research HUB Network 5 "Core competences". She is an author of 40 scientific papers and 10 books and monographs.

ORCID ID: orcid.org/0000-0002-4835-3943

Svetlana SURIKOVA, Dr.paed. is a leading researcher in the Scientific Institute of Pedagogy at the Faculty of Education, Psychology and Art of the University of Latvia. Her scientific interests are related to the research of professionalization of adult educators, effectiveness and quality assurance in adult and continuing education as well as interaction between social innovation and education, challenges faced to the promotion of social innovation from the perspective of education.

ORCID ID: orcid.org/0000-0002-3025-6344

Konstantins KOZLOVSKIS, Dr.oec. is an associated professor at the Faculty of Engineering Economics and Management of Riga Technical University. His fields of expertice are econometric modeling, investment management, financial markets, financial instruments, quantitative trading strategy development, implementation of mathematics, statistics, and information technologies in real conditions used for different purposes by academic and business entities. He is an author of more than 30 scientific papers and 12 books.

ORCID ID: orcid.org/0000-0003-3384-4499

Anna SVIRINA graduated from Kazan State Technical University in 2001, and got doctoral degree in economics in 2011 in management and economics of enterprises. Prior to start academic career, she worked as an accountant and entrepreneur. Her research interests are entrepreneurship, social business, managerial efficiency. Anna is currently working on development of quality management research center at Kazan National Research Technical University.

ORCID ID: orcid.org/0000-0001-8598-558X

Register for an ORCID ID:

https://orcid.org/register

Copyright (C) 2018 by author(s) and VsI Entrepreneurship and Sustainability Center

This work is licensed under the Creative Commons Attribution International License (CC BY).

http://creativecommons.org/licenses/by/4.0/

c) (†) Open Access 